\title{
Dual Protective Effects of Flavonoids from Petasites japonicus against UVB-Induced Apoptosis Mediated via HSF-1 Activated Heat Shock Proteins and Nrf2-Activated Heme Oxygenase-1 Pathways
}

\author{
Ki Mo Kim, ${ }^{a, b, \#}$ A-Rang Im, ${ }^{a, \#}$ Sanghyun Lee, ${ }^{c}$ and Sungwook Chae*,a,b \\ ${ }^{a}$ KM Convergence Research Division, Korea Institute of Oriental Medicine; 1672 Yuseong-daero, Yuseong-gu, \\ Daejeon 34054, Republic of Korea: ${ }^{b}$ University of Science and Technology; 217 Gajeong-ro, Yuseong-gu, Daejeon \\ 34113, Republic of Korea: and ${ }^{c}$ Department of Integrative Plant Science, Chung-Ang University; Anseong 17546, \\ Republic of Korea. \\ Received August 30, 2016; accepted February 16, 2017
}

The leaves of Petasites japonicus are used for their anti-allergic properties in traditional Korean, Japanese, and Chinese medicine. This study aimed to identify bioactive compounds isolated from $P$. japonicus leaves. All compounds were assessed for their ability of transcriptional activation, induction of phase 2 enzymes and heat shock proteins (HSPs), as well as protection against the UVB-induced apoptotic cell death. Bioactive compounds were isolated from $P$. japonicus leaves. All compounds were evaluated for their protective effect using human dermal fibroblasts (HDF) and human epidermal keratinocyte cells (HEKC) treated with UVB radiation. Four flavonoids were isolated from the leaves of $P$. japonicus and identified as kaempferol-3- $O$-(6"-acetyl)- $\beta$-D-glucoside (1), quercetin-3- $O$-(6"-acetyl)- $\beta$-D-glucoside (2), kaempferol-3- $O$ - $\beta$ D-glucoside (3), and quercetin-3-O- $\beta$-D-glucoside (4). These compounds activated nuclear factor (erythroidderived 2)-like 2 (Nrf2) and heat-shock response transcription elements (HSE) that resulted in the induction of heme oxygenase-1 (HO-1) and HSP70, respectively. Activation of these pathways provided protection to the skin cells against UVB radiation. The isolated compounds activated the Nrf2 and HSE pathways and could protect against UVB-induced apoptosis.

Key words Petasites japonicus; antioxidant response element; heme oxygenase-1; heat-shock response transcription element; apoptosis; UVB radiation

Extracts from Petasites genus have shown anti-allergic and anti-inflammatory effects. ${ }^{1,2)}$ The aerial parts of $P$. japonicus have been shown to have anti-allergic property against type I reactions and to inhibit the mast cell degranulation identified suppressive effects of $P$. japonicus extracts on ovalbumin-induced airway inflammation using an asthmatic mouse model. ${ }^{1,3)}$ However, the active constituents of $P$. japonicus leaves have not been fully studied. Recently, it has been shown that electrophilic compounds can induce the expression of a set of antioxidant enzymes, called phase 2 enzymes, which include heme oxygenase-1 (HO-1), reduced nicotinamide adenine dinucleotide phosphate (NADPH) quinone oxidoreductase (NQO1), and the $\mathrm{Na}^{+}$-independent cysteine-glutamate exchanger $(\mathrm{xCT})$, all of which provide efficient cytoprotection by regulating the intracellular redox state. $^{4-7)}$ Nuclear factor (erythroid-derived 2)-like 2 (Nrf2), a transcription factor released from Keapl in the cytoplasm, enters the nucleus and binds to the antioxidant response elements (AREs), ${ }^{8,9)}$ which stimulates the transcription of phase 2 enzyme genes. ${ }^{10)}$ The induction of molecular chaperones, including heat shock proteins (HSPs) (such as HSP70 and DnaJ) and heat-shock factor-binding proteins (HSBP), is another powerful endogenous protective mechanism. These molecular chaperones are known to suppress protein misfolding. ${ }^{11,12)}$ The expression of molecular chaperones after exposure to various types of cell stress is regulated by heat-shock-factor (HSF)-1. Under unstressed conditions, HSF-1 is localized in the cytosol and exists as an inactive form in a protein complex with

\footnotetext{
\# These authors contributed equally to this work.

* To whom correspondence should be addressed. e-mail: Kendall@kiom.re.kr
}

HSP90. Upon exposure to stress-inducing compounds, HSF-1 dissociates from the HSP90 protein complex, translocates into the nucleus, and binds to the HSF-1 promoter regions of various molecular chaperone genes to induce their expression. ${ }^{13)}$ In this study, bioactive compounds isolated from $P$. japonicus leaves were investigated for their protective effects against the UVB-induced skin cell death. We found that the protective effect of these bioactive compounds might be mediated by activation of the HSF-1/heat-shock response transcription elements (HSE) and Nrf2/ARE pathways.

\section{MATERIALS AND METHODS}

Plant Material and Chemicals Petasites japonicus leaves were supplied by Korea National Arboretum, Republic of Korea. A voucher specimen was deposited at the Herbarium of Department of Integrative Plant Science, Chung-Ang University, Anseong, Korea. Antibodies against HO-1, HSP70, Nrf2, HSF-1, Lamin B, and $\beta$-actin were purchased from Cell Signaling Technology (Beverly, MA, U.S.A.). Antioxidant Response Reporter kit (ARE-luciferase assay) and Heat Shock Element reporter kit (HSE luciferase assay) were purchased from SABiosciences (Frederick, MD, U.S.A.). All other reagents were purchased from Sigma-Aldrich (St. Louis, MO, U.S.A.) unless otherwise indicated. Purified compounds were dissolved in dimethyl sulfoxide (DMSO) and stored at $-80^{\circ} \mathrm{C}$. Solvent was used as elution solution on open chromatography, such as $\mathrm{MeOH}, n$-hexane, $\mathrm{CHCl}_{3}$, EtOAc, and $n$ - $\mathrm{BuOH}$ (SamChun Pure Chemical Co., Pyeongtaek, Korea).

Extraction and Isolation Dried and powdered P. japoni- 


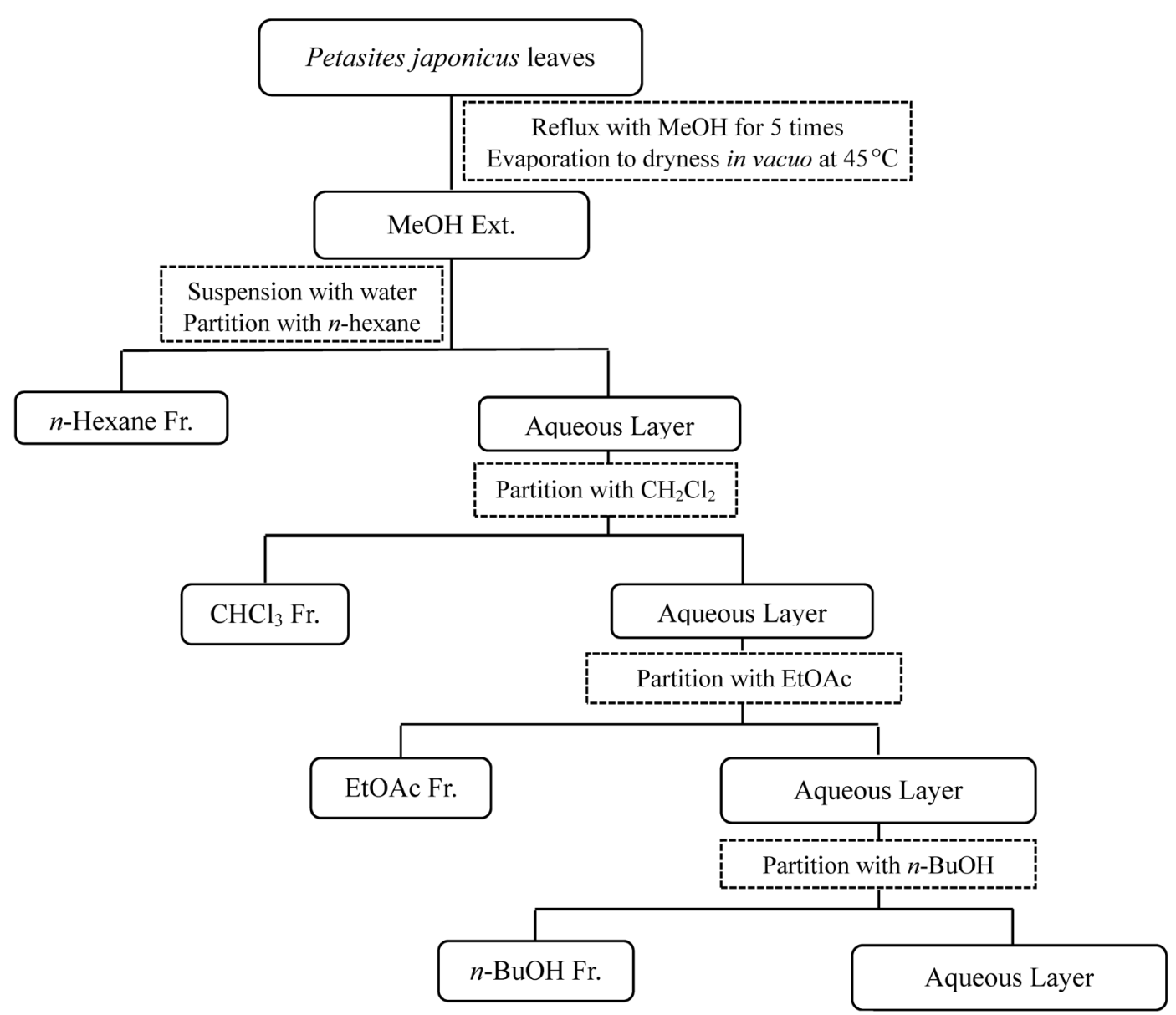

Chart 1. Extraction and Fractionation of $P$. japonicus

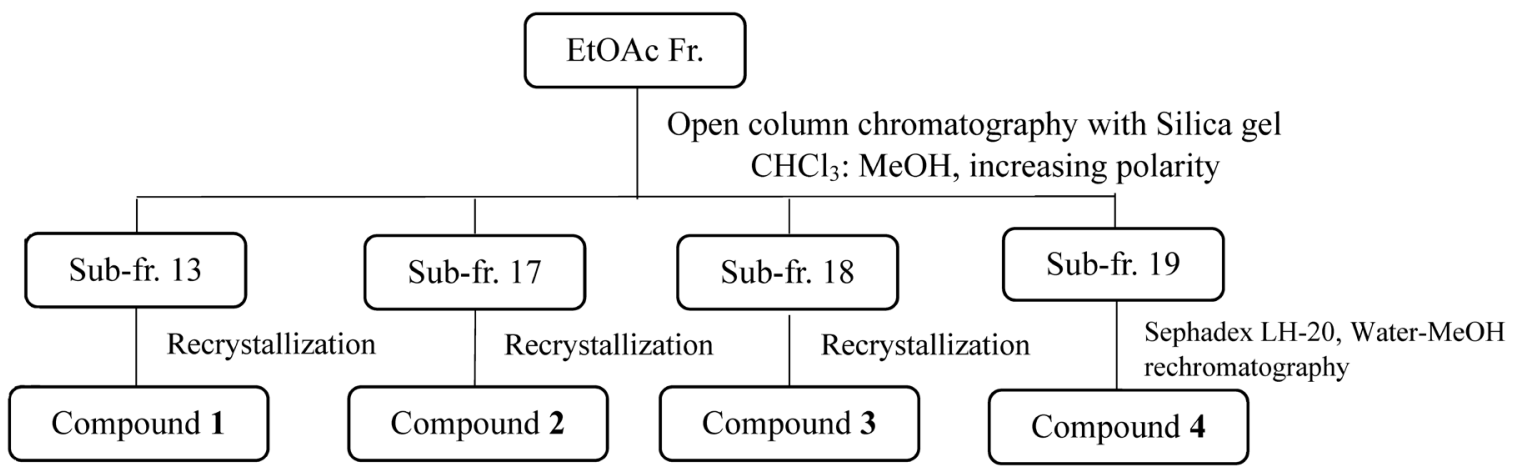

Chart 2. Isolation of Compounds $\mathbf{1}-\mathbf{4}$

cus leaves $(2950 \mathrm{~g})$ were extracted with $\mathrm{MeOH}(8 \mathrm{~L} \times 5)$ under reflux at $65-75^{\circ} \mathrm{C}$ (Chart 1). Filtrate was concentrated until dry in vacuo to produce $\mathrm{MeOH}$ extract $(541.9 \mathrm{~g})$, suspended in $\mathrm{H}_{2} \mathrm{O}$, and then partitioned using $n$-hexane $(37 \mathrm{~g}), \mathrm{CHCl}_{3}(24 \mathrm{~g})$, EtOAc $(17 \mathrm{~g})$, and $\mathrm{BuOH}(35 \mathrm{~g})$, in that order. A portion of the EtOAc fraction $(31.3 \mathrm{~g})$ was chromatographed on a silica gel column $(6 \times 80 \mathrm{~cm}$, No. 7734$)$ using a stepwise gradient of the $\mathrm{CHCl}_{3}-\mathrm{MeOH}$ solvent system to yield twenty nine subfractions. By recrystallization $\left(\mathrm{CHCl}_{3}-\mathrm{MeOH}\right)$, subfractions 13 , 17, and 18 yielded compounds $\mathbf{1}, \mathbf{2}$ and $\mathbf{3}$, respectively. Subfraction $19(0.3 \mathrm{~g})$ was processed with Sephadex LH-20 eluted with $\mathrm{CHCl}_{3}-\mathrm{MeOH}$ to yield subfractions 19.1-19.10. Subfr. 19-6 yielded subfractions 19.6.1-19.6.17 upon Sephadex LH-20 rechromatography. Subfraction 19.6.14.24 also was processed with rechromatography, and yielded compound 4 (subfraction 19.6.14.24.9.15) (Chart 2).

Purity of Isolated Compounds The purity was measured by calculating the area of the respective peaks in the chromatogram and calculating the percentage of pectolinarigenin. HPLC analysis was carried out using a binary pump (Waters 1525, Milford, MA, U.S.A.) equipped with an UV/Vis detector (Waters 2489). The purity of four isolated compounds were analyzed on a C18 reversed phase column (INNO column, Young Jin Biochrom Co., Seongnam, Gyeonggi, South Korea, $250 \times 4.6 \mathrm{~mm}, 5 \mu \mathrm{m}$ ) at room temperature with a sample injection volumn of $10 \mu \mathrm{L}$. The mobile phase consisted of water containing $0.5 \%$ acetic acid (A) and acetonitrile (B) using a gradient program of $17-30 \%$ B for $0-10 \mathrm{~min}, 30 \%$ 
Table 1. ${ }^{1} \mathrm{H}-\mathrm{NMR}$ Spectral Data for Compounds $\mathbf{1 - 4}(\mathrm{J}$ in $\mathrm{Hz})$ in DMSO

\begin{tabular}{ccccc}
\hline \hline No. & $\mathbf{1}$ & $\mathbf{2}$ & $\mathbf{3}$ & $\mathbf{4}$ \\
\hline 6 & $6.17(\mathrm{~d}, 1.5)$ & $6.22(\mathrm{~d}, 2.0)$ & $6.20(\mathrm{~d}, 2.0)$ & $6.19(\mathrm{~d}, 2.0)$ \\
8 & $6.40(\mathrm{~d}, 1.5)$ & $6.42(\mathrm{~d}, 2.0)$ & $6.43(\mathrm{~d}, 2.0)$ & $6.39(\mathrm{~d}, 2.0)$ \\
$2^{\prime}$ & $7.99(\mathrm{~d}, 8.5)$ & $7.55(\mathrm{~d}, 2.0)$ & $8.04(\mathrm{~d}, 8.5)$ & $7.58(\mathrm{~d}, 2.0)$ \\
$3^{\prime}$ & $6.87(\mathrm{~d}, 8.5)$ & - & $6.88(\mathrm{~d}, 8.5)$ & - \\
$5^{\prime}$ & $6.87(\mathrm{~d}, 8.5)$ & $6.84(\mathrm{~d}, 6.5)$ & $6.88(\mathrm{~d}, 8.5)$ & $6.84(\mathrm{~d}, 9.0)$ \\
$6^{\prime}$ & $7.99(\mathrm{~d}, 8.5)$ & $7.54(\mathrm{dd}, 2.0,6.5)$ & $8.04(\mathrm{~d}, 8.5)$ & $12.61(\mathrm{~s})$ \\
$5-\mathrm{OH}$ & $12.54(\mathrm{~s})$ & $12.61(\mathrm{~s})$ & $5.45(\mathrm{~d}, 7.5)$ & $5.46(\mathrm{dd}, 2.0,8.7)$ \\
$\mathrm{Glc}-1^{\prime \prime}$ & $5.34(\mathrm{~d}, 7.5)$ & $5.39(\mathrm{~d}, 7.5)$ & \\
$6^{\prime \prime}-\mathrm{Ha}$ & $4.10(\mathrm{dd}, 2.0,11.5)$ & $4.13(\mathrm{dd}, 2.0,11.5)$ & & \\
$6^{\prime \prime}-\mathrm{Hb}$ & $3.95(\mathrm{q}, 6.0,11.5)$ & $3.96(\mathrm{q}, 6.0,11.5)$ & & \\
$-\mathrm{COC}{ }_{3}$ & $1.74(\mathrm{~s})$ & $1.74(\mathrm{~s})$ & & \\
\hline
\end{tabular}

Chemical shifts are reported in parts per million $(\delta)$, and coupling constants $(J)$ are expressed in Hertz.

B for $10-25 \mathrm{~min}, 30-80 \% \mathrm{~B}$ for $25-30 \mathrm{~min}$, and $100 \% \mathrm{~B}$ for $30-40 \mathrm{~min}$. The flow rate was $1.0 \mathrm{~mL} / \mathrm{min}$. The purity of four compounds (1-4) were analyzed as 96.2, 92.3, 99, and 99\%, respectively (data not shown).

Cell Culture and Cell Viability Assay Human dermal fibroblasts (HDF) cell line was obtained from ScienCell (Carlsbad, CA, U.S.A.). HDF cells were propagated in fibroblast medium supplemented with $5 \%$ fetal bovine serum (FBS), 1\% fibroblast growth supplement, and 1\% penicillin and streptomycin $(\mathrm{P} / \mathrm{S})$. Human epidermal keratinocyte cells (HEKC) were purchased from Lonza (Walkersville, MD, U.S.A.) and maintained in KGM-Gold ${ }^{\mathrm{TM}}$ SingleQuots $^{\mathrm{TM}}$ medium kit containing supplements and growth factors. Both cell lines were maintained in a humidified $5 \% \mathrm{CO}_{2}$ incubator at $37^{\circ} \mathrm{C}$. Viabilities of HDF and HEKC were measured by an 3-(4,5-dimethylthiazol-2-yl)-2,5-diphenyltetrazolium bromide (MTT) assay as previously described. ${ }^{14}$

Real Time Quantitative PCR (qPCR) The total cellular RNA was extracted using Trizol reagent according to the manufacturer's instructions (Thermo Fisher Scientific, Waltham, MA, U.S.A.). To quantify the gene expression in HDF and HEKC, RT-PCR was performed with TaqMan universal PCR Master Mix (Applied Biosystems, Waltham, MA, U.S.A.) using ABI QuantStudio ${ }^{\mathrm{TM}} 6$ Flex Real-Time PCR system (Applied Biosystems). The relative mRNA expression levels of HO-1 and HSPA8 were normalized to that of $\beta$-actin. The PCR protocol used was as follows: 40 cycles at $95^{\circ} \mathrm{C}$ for $15 \mathrm{~s}$ and $60^{\circ} \mathrm{C}$ for $1 \mathrm{~min}$. Each sample was assayed in triplicate and relative mRNA expression levels were calculated using the $\Delta \Delta \mathrm{Ct}$ method.

Preparation of Cytosolic and Nuclear Fractions Cytosolic and nuclear fractions were prepared using NE-PER ${ }^{\mathrm{TM}}$ Nuclear and Cytoplasmic Extraction Reagent Kit (Fisher Scientific). Briefly, cells were trypsinized and suspended in cell fractionation buffer for $5 \mathrm{~min}$. The suspension was centrifuged at $500 \times \boldsymbol{g}$ for $5 \mathrm{~min}$ at $4^{\circ} \mathrm{C}$ and the supernatant containing the cytoplasmic fraction was collected. The pellet containing the nuclear fraction was re-suspended in ice-cold cell disruption buffer, vortexed, and incubated for $5 \mathrm{~min}$ on ice to ensure complete cell disruption. Nuclear Nrf2 and HSF-1 was detected by Western blotting.

Western Blotting Cell lysates were prepared from HDF and HEKC $\left(5 \times 10^{6}\right)$ in $1 \times$ Laemmli lysis buffer $(2.4 \mathrm{M}$ glycerol, $0.14 \mathrm{M}$ Tris ( $\mathrm{pH} 6.8$ ), $0.21 \mathrm{~m}$ sodium dodecyl sulfate, and $0.3 \mathrm{~mm}$ bromophenol blue), and boiled for $10 \mathrm{~min}$. The protein
Table 2. ${ }^{13} \mathrm{C}$-NMR Spectral Data for Compounds $\mathbf{1}-\mathbf{4}$ in DMSO

\begin{tabular}{|c|c|c|c|c|}
\hline No. & 1 & 2 & 3 & 4 \\
\hline 2 & 155.9 & 156.0 & 155.7 & 158.5 \\
\hline 3 & 132.6 & 132.6 & 132.7 & 135.6 \\
\hline 4 & 176.9 & 176.9 & 176.9 & 179.5 \\
\hline 5 & 160.7 & 160.7 & 160.7 & 163.1 \\
\hline 6 & 98.2 & 98.2 & 98.2 & 99.8 \\
\hline 7 & 163.8 & 169.4 & 163.7 & 166.1 \\
\hline 8 & 93.2 & 93.0 & 93.1 & 94.6 \\
\hline 9 & 156.1 & 155.8 & 155.9 & 158.9 \\
\hline 10 & 103.4 & 103.4 & 103.4 & 105.4 \\
\hline $1^{\prime}$ & 120.3 & 120.6 & 120.4 & 123.2 \\
\hline $2^{\prime}$ & 130.3 & 114.6 & 130.4 & 116.4 \\
\hline $3^{\prime}$ & 114.5 & 144.3 & 114.6 & 145.6 \\
\hline $4^{\prime}$ & 159.5 & 148.0 & 159.4 & 149.4 \\
\hline $5^{\prime}$ & 114.5 & 115.7 & 114.6 & 117.6 \\
\hline $6^{\prime}$ & 130.3 & 121.0 & 130.4 & 123.4 \\
\hline Glc-1 & 100.6 & 100.5 & 100.3 & 104.3 \\
\hline Glc-2 & 73.4 & 69.3 & 73.7 & 75.7 \\
\hline Glc-3 & 73.6 & 73.5 & 75.9 & 78.9 \\
\hline Glc-4 & 69.3 & 62.3 & 69.4 & 71.4 \\
\hline Glc-5 & 75.6 & 75.7 & 77.0 & 78.0 \\
\hline Glc-6 & 62.2 & 59.3 & 60.3 & 62.3 \\
\hline$-\mathrm{COCH}_{3}$ & 169.3 & 169.4 & - & - \\
\hline$-\mathrm{COCH}_{3}$ & 19.6 & 19.6 & - & - \\
\hline
\end{tabular}

content was measured using the BCA protein assay reagent (Pierce, Waltham, MA, U.S.A.). Protein samples $(20 \mu \mathrm{g})$ were diluted with $1 \times$ lysis buffer, separated by electrophoresis (4.5-15\% gradient), and transferred onto polyvinylidene fluoride membranes (PVDF). The membranes were then incubated with primary antibodies against $\operatorname{Nrf2}(1: 1000)$, HSF-1 (1:1000), HO-1 (1:1000), HSP70 (1:1000), Lamin B $(1: 1000)$, and $\beta$-actin $(1: 1000)$ for overnight. Subsequently, the membranes were incubated with horseradish peroxide-conjugated secondary antibodies, and detected using an enhanced chemiluminescence detection system from Amersham Bioscience (Buckinghamshire, U.K.). Protein expression levels were determined by analysis of the signals captured using an image analyzer (Las-3000, FUJIFILM, Tokyo, Japan).

Transient Transfection and Luciferase Assay The effects of isolated compounds on ARE and HSE activity were assayed in a Luciferase Reporter Assay System (SABiosciences, Frederick, MD, U.S.A.). Brief, HDF and HEKC were 
A<smiles></smiles>

1<smiles>O=C(CO)Oc1c(-c2ccc(O)cc2)oc2cc(O)cc(O)c2c1=O</smiles>

3<smiles>CC(=O)OCCOC(=O)Oc1c(-c2ccc(O)c(O)c2)oc2cc(O)cc(O)c2c1=O</smiles>

2<smiles>O=c1c(OCC(O)CO)c(-c2ccc(O)c(O)c2)oc2cc(O)cc(O)c12</smiles>

4
B HDF control

\& compound 1

compound 2

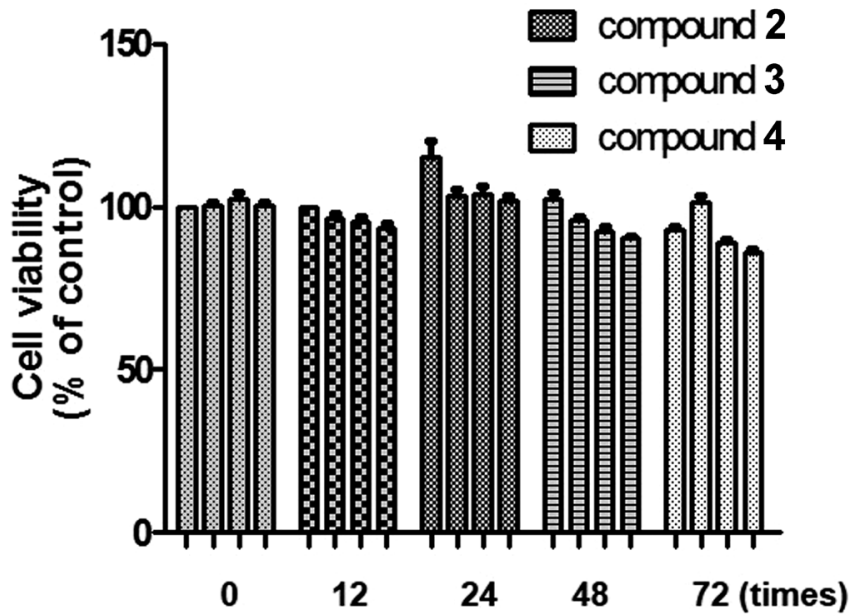

HEKC

C

kaempferol-3-O-(6"-acetyl)- $\beta$-D-glucoside (1) quercetin-3-O-(6"-acetyl)- $\beta$-D-glucoside (2) kaempferol-3-O- $\beta$-D-glucoside (3) quercetin-3-O- $\beta$ - $D$-glucoside (4)

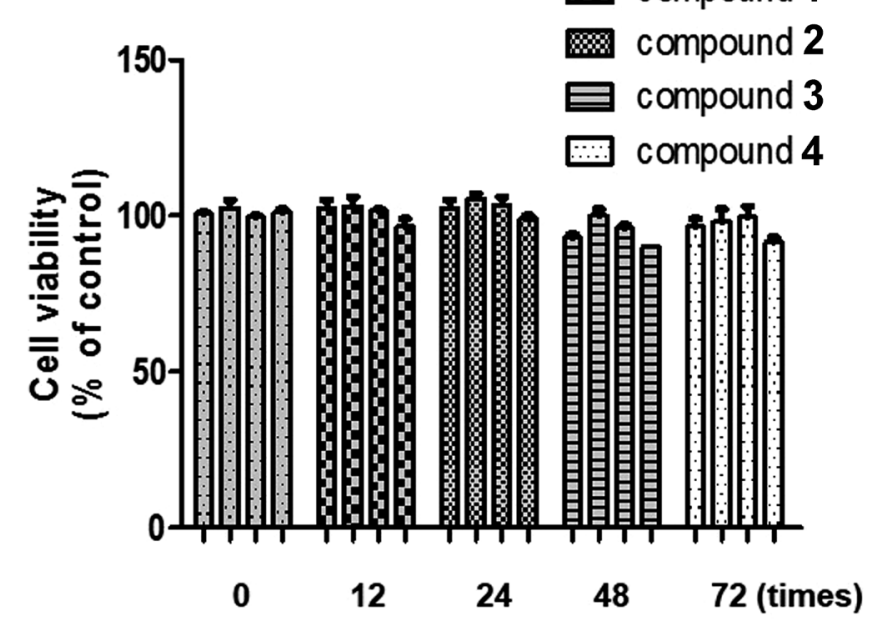

Fig. 1. Cytotoxic Effect of the Bioactive Compounds Isolated from Petasites japonicus Leaves on HDF and HEKC

(A) Chemical structures of the bioactive compounds. (B and C) HDF and HEKC viabilities were assessed using the MTT assay. Cells ( $1 \times 10^{5}$ cells $/ \mathrm{mL}$ ) were incubated with $10 \mu \mathrm{g} / \mathrm{mL}$ of compounds for indicated time intervals followed by incubation with MTT solution for $4 \mathrm{~h}$. Each value is expressed as the mean \pm S.D. $(n=3)$.

seeded at a density of $1 \times 10^{5}$ cells/well in 6 well plates and grown to $60-70 \%$ confluence. Cells were then transfected with $100 \mathrm{ng}$ of ARE and HSE luciferase reporter construct using Lipofectamine $^{\mathrm{TM}} 2000$ transfection reagent according to the manufacturer's protocol (Invitrogen, Carlsbad, CA, U.S.A.). Renilla-CMV luciferase was used to correct for the transfection efficiency. Twelve hours after transfection, cells were treated with the compounds for $24 \mathrm{~h}$. After incubation, cell lysis was carried out using the reporter lysis buffer. Cell extracts were then mixed with a luciferase substrate (Promega, Madison, WI, U.S.A.), and luciferase activity was determined using Tristar LB 941 multimode microplate reader (Tristar, Berthold, Wildbad, Germany).

Terminal Deoxynucleotidyl Transferase-Mediated Deoxyuridine Triphosphate Nick-End Labeling (TUNEL) Assay HDF and HEKC were plated at $1 \times 10^{4}$ cells $/ \mathrm{mL}$ in chamber slides. Cells were treated with compounds for $12 \mathrm{~h}$ and then exposed to UVB radiation $\left(50 \mathrm{~mJ} / \mathrm{cm}^{2}\right)$ for $60 \mathrm{~min}$.
Apoptosis was assessed by a fluorescence TUNEL assay kit according to the manufacturer's recommendations (Roche-Applied Science, Indianapolis, IN, U.S.A.). Images were captured using an inverted-fluorescence microscope (Olympus IX71, Tokyo, Japan). At least 100 TUNEL-positive cells were scored for each experiment performed in triplicate.

Statistical Analysis The data are presented as the mean \pm standard deviation (S.D.) of at least three separate experiments. Comparisons between two groups were made using the Student's $t$-test in Graph Pad Software (San Diego, CA, U.S.A.); significance was established at $p<0.05$.

\section{RESULTS}

Isolation of Flavonoids Four flavonoids were identified as kaempferol-3- $O$-(6"-acetyl)- $\beta$-D-glucoside (1, $15 \mathrm{mg})$, quercetin-3- $O$-(6"-acetyl)- $\beta$-D-glucoside $\quad(2,12 \mathrm{mg})$, kaempferol-3- $O$ - $\beta$-D-glucoside $(3,11 \mathrm{mg})$, and quercetin-3- 

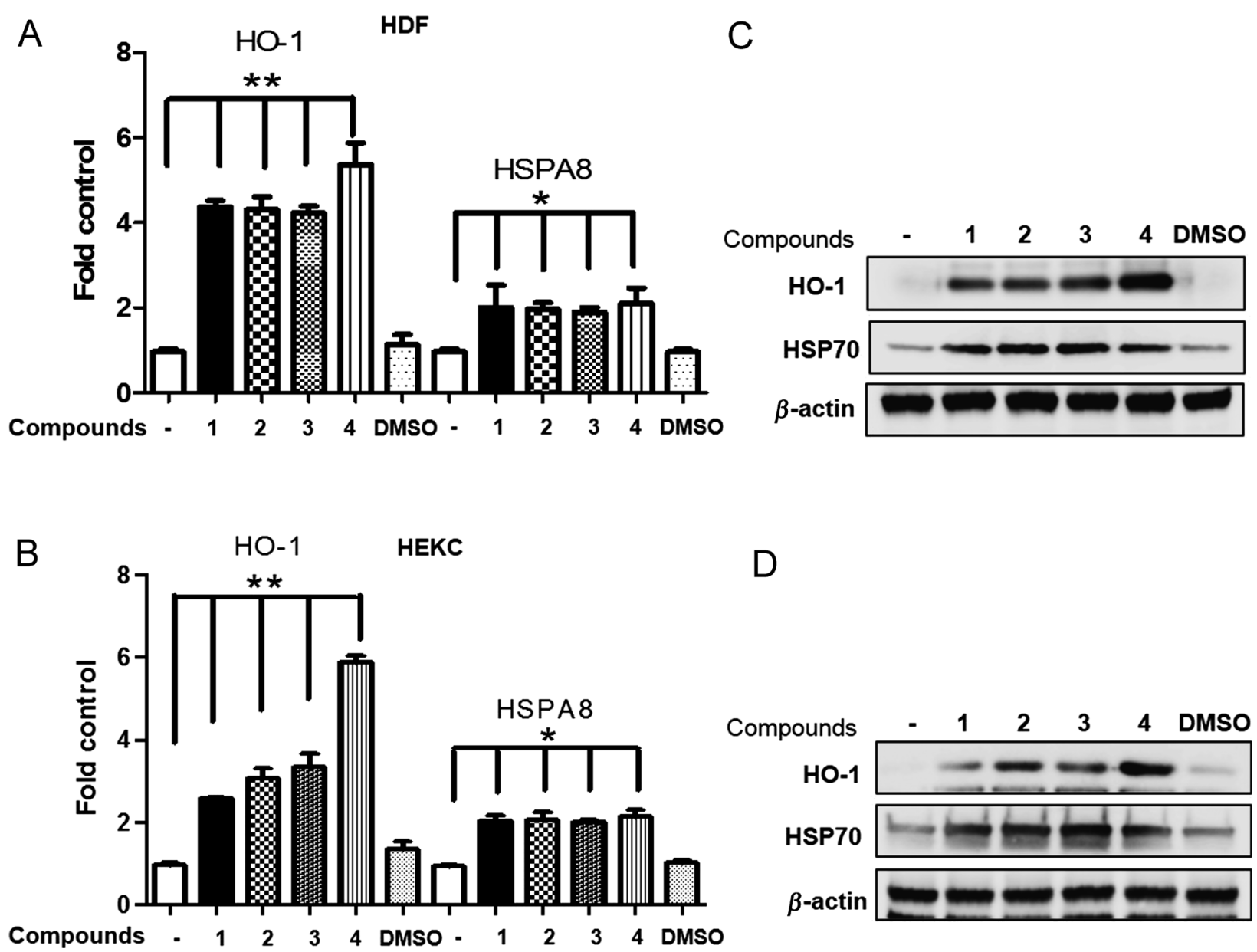

Fig. 2. Induction of Phase 2 Enzymes and HSPs by Bioactive Compounds Isolated from Petasites japonicus Leaves

(A and B) PCR analysis of HO-1 and HSPA8 gene induction by the compounds. Total RNAs were extracted from HDF and HEKC after treatment with $10 \mu \mathrm{g} / \mathrm{mL}$ of compounds for $8 \mathrm{~h}$. RT-PCR was performed with the specific primers listed in the 'Materials and Methods.' Each value is expressed as the mean \pm S.D. $(n=3)$. ${ }^{*} p<0.05$ and $* * p<0.01$ indicate significant difference versus control. (C and D) Cells were treated with $10 \mu \mathrm{g} / \mathrm{mL}$ of the compounds for $12 \mathrm{~h}$. Protein expression of HO-1, HSP70, and $\beta$-actin were determined by Western blotting. The protein expressions were normalized to $\beta$-actin. The data from three independent experiments are expressed as the mean \pm S.D.

$O-\beta$-D-glucoside $(4,16 \mathrm{mg})$. Their chemical shifts are listed in Tables 1 and 2 .

Cytotoxic Effects of Compounds on HDF and HEKC The chemical structures of the major bioactive compounds isolated from Petasites japonicus leaves are presented in Fig. 1A. HDF and HEKC were incubated with the compounds at different concentrations for 12 and $72 \mathrm{~h}$ to evaluate the potential toxicity of the four compounds isolated from $P$. japonicus leaves. Cell viability was determined using the MTT assay (Figs. 1B, C). Treatment with $10 \mu \mathrm{g} / \mathrm{mL}$ of compounds showed no significant effect on the viability of HDK and HEKC, compared to that of the untreated cells.

Induction of Phase 2 Enzymes and HSP by the Compounds We hypothesized that the biological activity of these compounds would be closely related to their ability to activate the Nrf2/ARE pathway. Activation of Nrf2 and HSE transcriptional elements induces phase 2 enzymes and HSPs, respectively. A qPCR analysis was performed using primers for HO-1 and HSPA8 phase 2 genes (Figs. 2A, B). All compounds significantly induced the expression of both genes; however, the magnitude of induction among the genes was different. Subsequently, the induction of HO-1 and HSP70 at the protein level was confirmed by Western blotting analysis (Figs. $2 \mathrm{C}, \mathrm{D})$. All compounds increased the expression of HO-1 and
HSP70 proteins. These data suggested that the isolated compounds potently induced HSPs as well as phase 2 enzymes.

Translocation of Nrf2 and HSF-1 after Treatment with the Compounds Induction of phase 2 enzyme and HSPs is largely regulated by the transcription factors Nrf2 and HSF-1, respectively. For transcriptional activation, both factors must be in the nucleus. Therefore, the cellular distribution of Nrf2 and HSF-1 was determined in the presence of compounds. Nrf2 translocates from the cytoplasm into the nucleus after dissociation from Keapl. In this study, all compounds increased the nuclear accumulation of Nrf2 and HSF-1 (Figs. $3 \mathrm{~A}, \mathrm{~B})$. These results show that the bioactive compounds isolated from Petasites japonicus leaves increase the concentration of Nrf2 and HSF-1 in the nucleus, which in turn could upregulate HO-1 and HSPs.

Activation of ARE and HSE after Treatment with Compounds A reporter gene assay was performed in HDF and HEKC. Cells were transfected with cDNAs under transcriptional control for ARE and HSE (Figs. 4A, B). Results showed that all compounds significantly activated both transcriptional elements. This indicated that the bioactive compounds activated both the Nrf2/ARE and HSF-1/HSE system.

Protective Effect of Compounds against UVB-Induced Apoptosis in HDF and HEKC UVB radiation is well- 

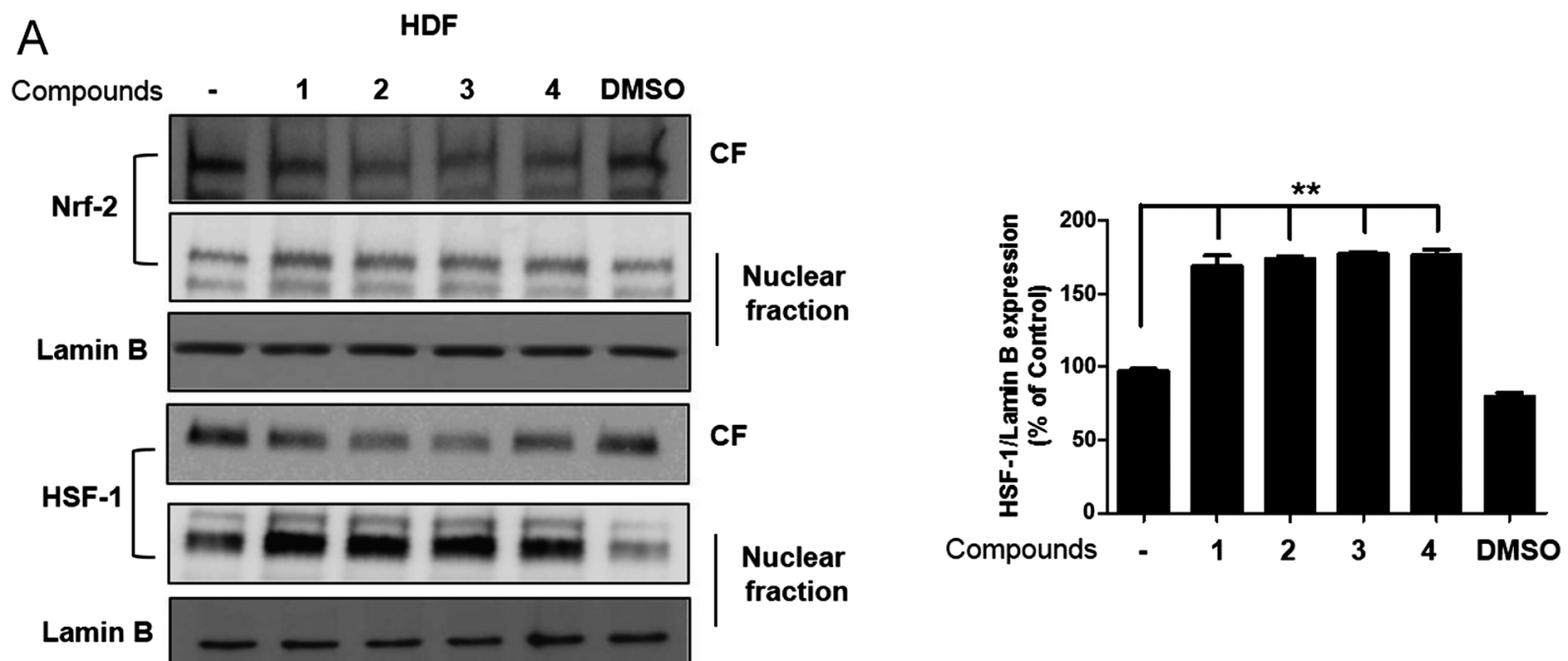

B

HEKC
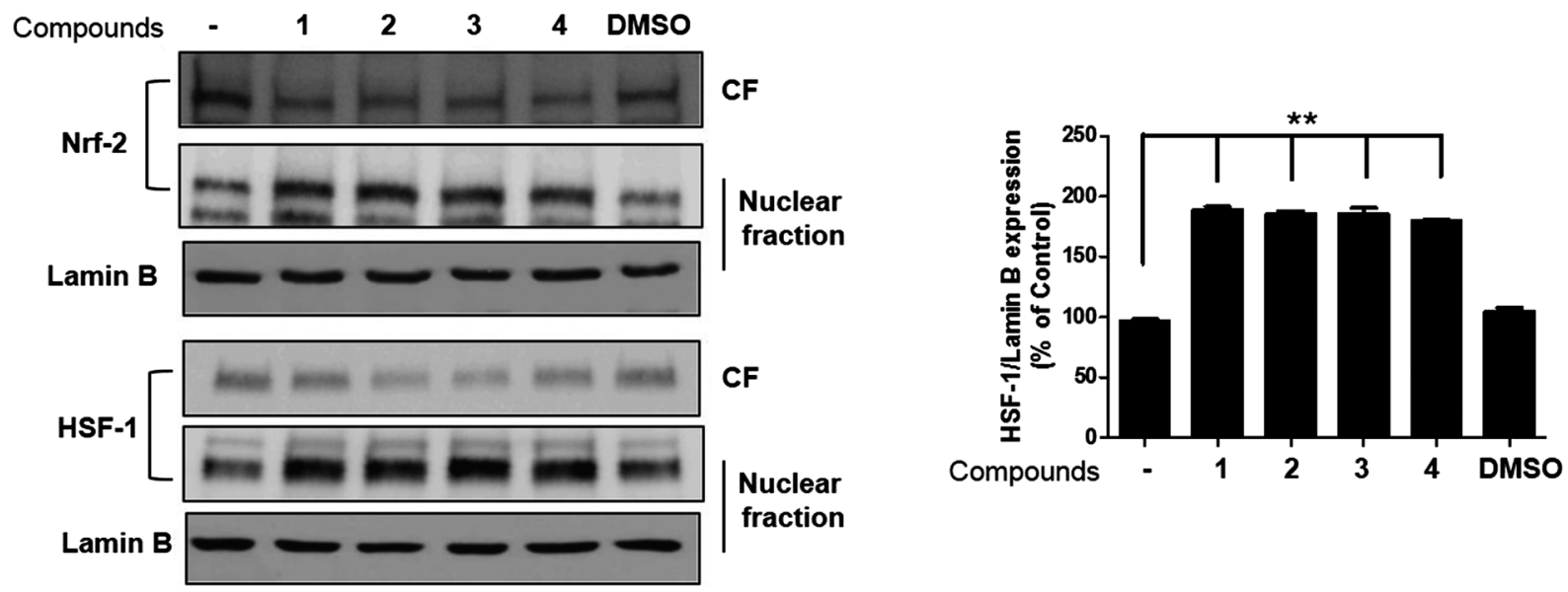

Fig. 3. Nuclear Translocation of Nrf2 and HSF-1 after Treatment with the Bioactive Compounds Isolated from Petasites japonicus Leaves

(A and B) HDF and HEKC $\left(5 \times 10^{5}\right.$ cells $\left./ \mathrm{mL}\right)$ were incubated with the compounds at the concentration of $10 \mu \mathrm{g} / \mathrm{mL}$ for $6 \mathrm{~h}$. Nuclear fraction (NF) and cytosolic fraction (CF) were prepared as described in Materials and Methods. The relative densities of nuclear fraction proteins (Nrf2 and HSF-1) were normalized to Lamin B. The data from three independent experiments are expressed as the mean \pm S.D., ${ }^{* *} p<0.01$ indicates significant difference from the untreated control group.

known for its capacity to aggravate apoptosis in human keratinocytes. ${ }^{15)}$ Therefore, the ability of isolated compounds to improve cell survival in the UVB radiation-induced apoptosis in HDF and HEKC cells was studied. TUNEL assay showed that pretreatment with the isolated compounds significantly decreased the high level of DNA fragmentation in UVBirradiated cells (Figs. 5A, B).

\section{DISCUSSION}

This study compared the biological activity of flavonoids isolated from Petasites japonicus leaves such as kaempferol-3$O$-(6"-acetyl)- $\beta$-D-glucoside (1), quercetin-3-O-(6"-acetyl)- $\beta$ D-glucoside (2), kaempferol-3- $O$ - $\beta$-D-glucoside (3), and quercetin-3- $O-\beta$-D-glucoside (4), according to their chemical structures. We evaluated the transcriptional activation, induction of phase 2 enzymes and HSPs, and cytoprotection against the UVB-induced damage, to compare the compounds 1, 2, 3, and 4, which share similar chemical backbone with different pattern of hydroxyl substitution and acetyl group in glucose moiety. The isolated compounds showed no cytotoxicity against the HDF and HEKC at concentration up to $10 \mu \mathrm{g} / \mathrm{mL}$ (Figs. 1B, C). Furthermore, it was found that these compounds increased the transcriptional activity of HO-1 and HSPA8 genes by two-fold to four-fold (Figs. 2A, B).

Previous studies have shown that activation of the Nrf2/ARE pathway is an important protective mechanism against electrophilic compounds. ${ }^{16,17)}$ Activation of endothelial nitric oxide synthase by dietary isoflavones: role of NO in Nrf2-mediated antioxidant gene expression. ${ }^{18)}$ The flavonoids quercetin and fisetin inhibited histamine release and expression of proinflammatory cytokines in mast cells ${ }^{19}$ and anti-artherosclerotic effect. ${ }^{20)}$ Dietary flavonoids are neuroprotective through Nrf2-coordinated induction of endogenous cytoprotective porteins. ${ }^{21)}$ This pathway represents an endogenous protective mechanism against oxidative stress. It stimulates the transcription of several phase 2 enzymes involved in redox regulation. Furthermore, it has been previously reported that the activation of Nrf2 stimulates HSP70 production. ${ }^{22)}$ Transcriptional induction of molecular chaperones is regulated by the stress-inducible heat transcription factor known as HSF-1, which plays a key regulatory role in the 
A

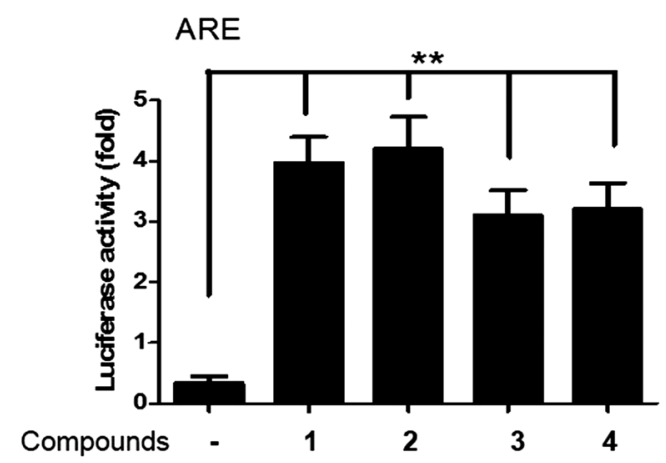

HDF

HSE

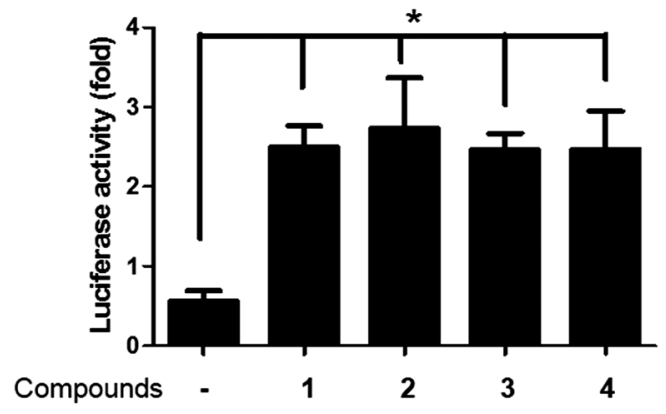

HEKC

B

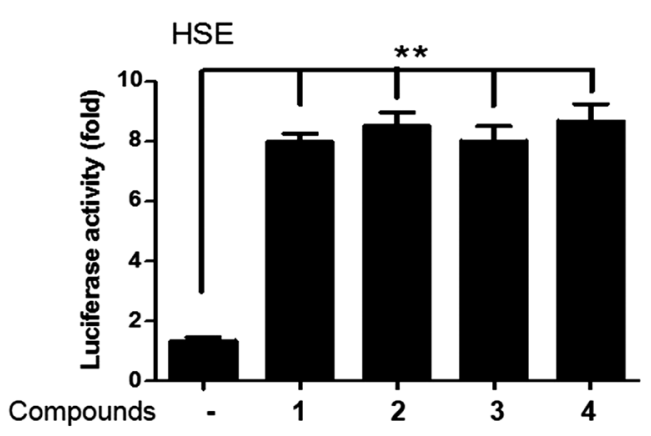

Fig. 4. Transcriptional Activation of ARE and HSE after Treatment with the Bioactive Compounds Isolated from Petasites japonicus Leaves

(A and B) HDF and HEKC $\left(2 \times 10^{5}\right.$ cells $\left./ \mathrm{mL}\right)$ were incubated with the compounds for $24 \mathrm{~h}$, and then transfected with plasmid DNAs (ARE- or HSE-luciferase construct). Cells were allowed to recover for $24 \mathrm{~h}$. Subsequently, cells were treated with $10 \mu \mathrm{g} / \mathrm{mL}$ of the compounds for $6 \mathrm{~h}$, and subjected to reporter gene assays. Each value is expressed as the mean \pm S.D. $(n=3)$. $* p<0.05$ and $* * p<0.01$ indicate significant difference versus control.
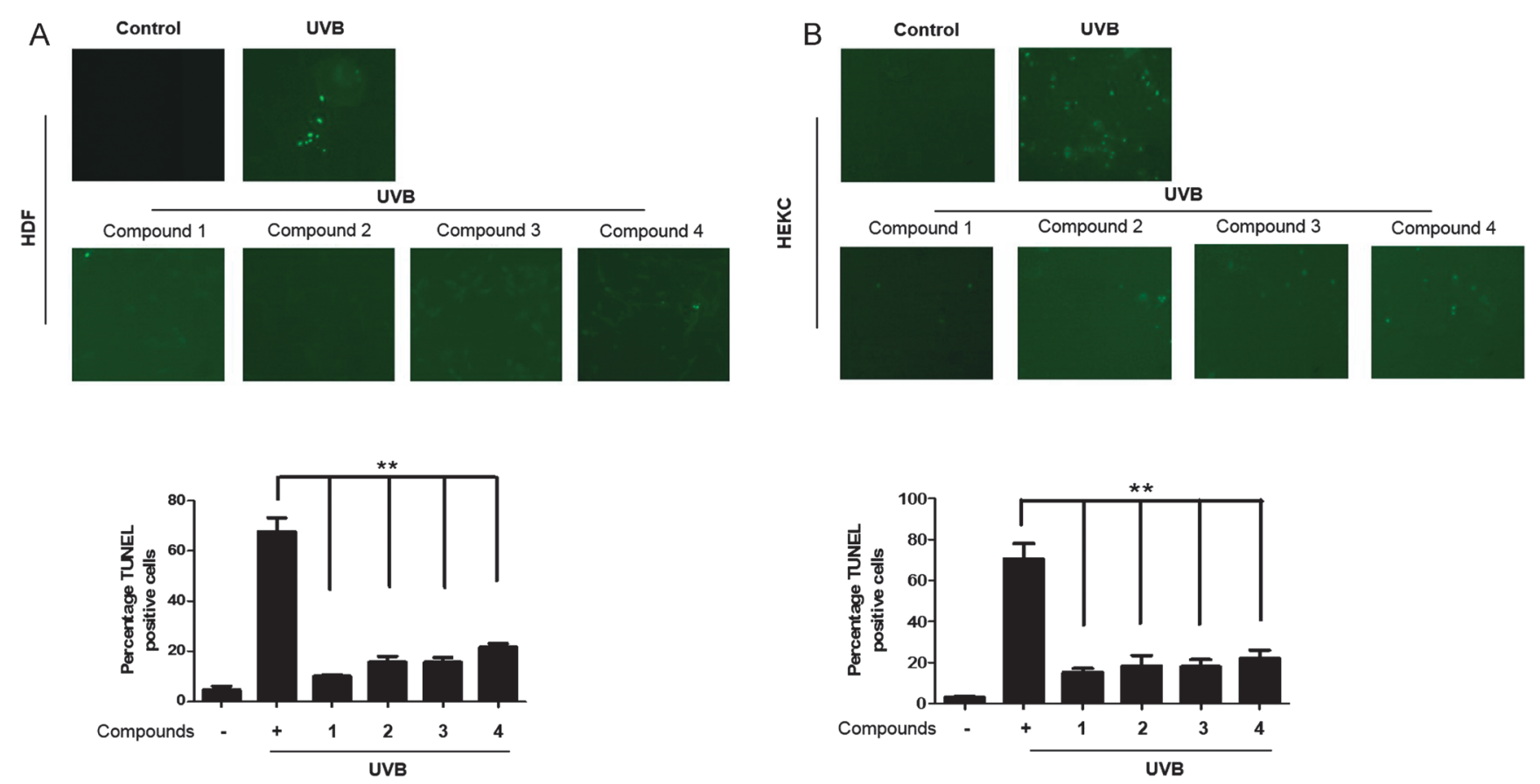

Fig. 5. The Bioactive Compounds Isolated from Petasites japonicus Leaves Ameliorate the UVB-Induced Apoptosis

(A and B) HDF and HEKC $\left(1 \times 10^{5}\right.$ cells $\left./ \mathrm{mL}\right)$ were pretreated with the compounds $(10 \mu \mathrm{g} / \mathrm{mL})$ for $12 \mathrm{~h}$, exposed to UVB light $\left(50 \mathrm{~mJ} / \mathrm{cm}^{2}\right)$ for $60 \mathrm{~min}$, and then incubated for $12 \mathrm{~h}$. Apoptotic cells were detected by the TUNEL assay and quantitated. Each value is expressed as the mean \pm S.D. $(n=3)$. ** $p<0.01$ indicates significant difference versus UVB light. 
response to environmental stress. ${ }^{23)}$ Therefore, the HSF-1/HSE system might provide protection against oxidative stress and UVB radiation. In this study, it was found that the compounds isolated from Petasites japonicus leaves increased the nuclear accumulation of Nrf2 and HSF-1 (Figs. 3A, B), and activated both transcriptional elements. This showed that both Nrf2/ARE and HSF-1/HSE pathways were activated (Figs. 4A, B). Although some electrophiles were shown to affect HSPs, ${ }^{24)}$ this is the first report of flavonoids inducing transcription of protective genes via activation of the HSF-1/HSE and Nrf2/ARE pathways.

UVB irradiation triggers cytotoxic damage to the skin, which interferes with the normal cellular function, and finally culminates in photodamage, photoaging, and photocarcinogenesis. ${ }^{25)}$ Furthermore, UVB light interacts with intracellular chromophores and photosensitizers to cause severe oxidative stress in the skin cells. It could cause transient as well as permanent genetic damage. At molecular level, these oxidative stress reactions activate cytoplasmic signal transduction pathways associated with cell growth, differentiation, and senescence. ${ }^{26)}$ Abnormal production of reactive oxygen species (ROS) results in oxidative damage to macromolecules, including DNA, lipids, and proteins. ${ }^{27)}$ Like apoptosis and mitochondrial dysfunction, macromolecular injury contributes to considerable disruption of the normal cellular function. Notably, the present study showed that pretreatment with the isolated compounds prevented DNA fragmentation in HDF and HEKC following exposure to UVB light (Figs. 5A, B).

In conclusion, findings of this study suggest that the bioactive compounds isolated from Petasites japonicus leaves activated Nrf2 and HSF-1 transcription, induced phase 2 enzymes and HSPs, and protected against the UVB-mediated apoptosis. However, other factors that govern drug ability, such as pharmacokinetics, bioavailability, stability, and metabolism, would also be important in determining the most effective compounds in vivo. Nonetheless, this is the first report to demonstrate that flavonoid compounds are an important determinant in the activation of Nrf2 and HSE-mediated stress responses.

Acknowledgment This work was supported by a Grant (K16301) from the Korea Institute of Oriental Medicine (KIOM).

Conflict of Interest The authors declare no conflict of interest.

\section{REFERENCES}

1) Lee JS, Yang EJ, Yun CY, Kim DH, Kim IS. Suppressive effects of Petasites japonicus extract on ovalbumin-induced airway inflammation in an asthmatic mouse model. J. Ethnopharmacol., 133, 551-557 (2011).

2) Zhang FJ, Wang Q, Wang Y, Guo ML. Anti-allergic effects of total bakkenolides from Petasites tricholobus in ovalbumin-sensitized rats. Phytother. Res., 25, 116-121 (2011).

3) Shimoda H, Tanaka J, Yamada E, Morikawa T, Kasajima N, Yoshikawa M. Anti-type I allergic property of Japanese butterbur extract and its mast cells degranulation inhibitory ingredients. $J$. Agric. Food Chem., 54, 2915-2920 (2006).

4) Itoh K, Tong KI, Yamamoto M. Molecular mechanism activating Nrf2-Keap1 pathway in regulation of adaptive response to electrophiles. Free Radic. Biol. Med., 36, 1208-1213 (2004).
5) Satoh T, Baba M, Nakatsuka D, Ishikawa Y, Aburatani H, Furuta K, Ishikawa T, Hatanaka H, Suzuki M, Watanabe Y. Role of hemeoxygenase-1 protein in the neuroprotective effects of cyclopentenone prostaglandin derivatives under oxidative stress. Eur. J. Neurosci., 17, 2249-2255 (2003).

6) Satoh T, Okamoto S, Cui J, Watanabe Y, Furuta K, Suzuki M, Tohyama K, Lipton SA. Activation of the Keap1/Nrf2 pathway for neuroprotection by electrophilic phase II inducers. Proc. Natl. Acad. Sci. U.S.A., 103, 768-773 (2006).

7) Satoh T, Lipton SA. Redox regulation of neuronal survival mediated by electrophilic compounds. Trends Neurosci., 30, 37-45 (2007).

8) Padmanabhan B, Tong KI, Ohta T, Nakamura Y, Scharlock M, Ohtsuji M, Kang MI, Kobayashi A, Yokoyama S, Yamamoto M. Structural basis for defects of Keap1 activivty provoked by its point mutations in lung cancer. Mol. Cell, 21, 689-700 (2006).

9) Wang XJ, Hayes JD, Higgins LG, Wolf CR, Dinkova-Kostova AT. Activation of the NRF2 signaling pathway by copper-mediated redox cycling of para- and ortho-hydroquinones. Chem. Biol., 17, 75-85 (2010).

10) Satoh T, Harada N, Hosoya T, Tohyama K, Yamamoto M, Itoh K. Keap1/Nrf2 system regulates neuronal survival as revealed through study of keapl gene-knockout mice. Biochem. Biophys. Res. Commun., 380, 298-302 (2009).

11) Morimoto RI. Proteotoxic stress and inducible chaperone networks in neurodegenerative disease and aging. Genes Dev., 22, 1427-1438 (2008).

12) Nakamura T, Lipton SA. Cell death: protein misfolding and neurodegenerative diseases. Apoptosis, 14, 455-468 (2009).

13) Trott A, West JD, Klaić L, Westerheide SD, Silverman RB, Morimoto RI, Morano KA. Activation of heat shock and antioxidant responses by the natural product celastrol: transcriptional signatures of a thiol-targeted molecule. Mol. Biol. Cell, 19, 1104-1112 (2008).

14) Im AR, Kim YH, Uddin MR, Lee HW, Chae SW, Kim YH, Jung WS, Kang BJ, Mun CS, Lee MY. Scutellaria baicalensis extracts and flavonoids protect rat L6 cells from antimycin A-induced mitochondrial dysfunction. Evid. Based Complement. Alternat. Med., 2012, 517965 (2012).

15) Schwarz A, Bhardwaj R, Aragane $Y$, Mahnke K, Riemann $H$, Metze D, Luger TA, Schwarz T. Ultraviolet-B-induced apoptosis of keratinocytes: evidence for partial involvement of tumor necrosis factor- $\alpha$ in the formation of sunburn cells. J. Invest. Dermatol., 104, 922-927 (1995).

16) Hseu YC, Chou CW, Senthil Kumar KJ, Fu KT, Wang HM, Hsu LS, Kuo YH, Wu CR, Chen SC, Yang HL. Ellagic acid protects human keratinocyte $(\mathrm{HaCaT})$ cells against UVA-induced oxidative stress and apoptosis through the upregulation of the HO-1 and Nrf-2 antioxidant genes. Food Chem. Toxicol., 50, 1245-1255 (2012).

17) Liu Y, Chan F, Sun H, Yan J, Fan D, Zhao D, An J, Zhou D. Resveratrol protects human keratinocytes HaCaT cells from UVA-induced oxidative stress damage by downregulating Keap1 expression. Eur. J. Pharmacol., 650, 130-137 (2011).

18) Mann GE, Rowlands DJ, Li FY, de Winter P, Siow RC. Activation of endothelial nitric oxide synthase by dietary isoflavones: role of $\mathrm{NO}$ in Nrf2-mediated antioxidant gene expression. Cardiovasc. Res., 75, 261-274 (2007).

19) Park HH, Lee S, Son HY, Park SB, Kim MS, Choi EJ, Singh TS, Ha JH, Lee MG, Kim JE, Hyun MC, Kwon TK, Kim YH, Kim SH. Flavonoids inhibits histamine release and expression of proinflammatory cytokines in mast cells. Arch. Pharm. Res., 31, 1303-1311 (2008).

20) Salvamani S, Gunasekaran B, Shaharuddin NA, Ahmad SA, Shukor MY. Antiartherosclerotic effects of plant flavonoids. Biomed. Res. Int., 2014, 480258 (2014).

21) Leonardo CC, Dore S. Dietary flavonoids are neuroprotective through Nrf2-coordinated induction of endogenous cytoprotective proteins. Nutr. Neurosci., 14, 226-236 (2011). 
22) Rinaldi Tosi ME, Bocanegra V, Manucha W, Gil Lorenzo A, Vallés PG. The Nrf2-Keap1 cellular defense pathway and heat shock protein 70 (Hsp70) response. Role in protection against oxidative stress in early neonatal unilateral ureteral obstruction (UUO). Cell Stress Chaperones, 16, 57-68 (2011).

23) Bukau B, Weissman J, Horwich A. Molecular chaperones and protein quality control. Cell, 125, 443-451 (2006).

24) Groeger AL, Freeman BA. Signaling actions of electrophiles: antiinflammatory therapeutic candidates. Mol. Interv., 10, 39-50 (2010).
25) Sander CS, Chang H, Hamm F, Elsner P, Thiele JJ. Role of oxidative stress and the antioxidant network in cutaneous carcinogenesis. Int. J. Dermatol., 43, 326-335 (2004).

26) Helenius M, Mäkeläinen L, Salminen A. Attenuation of NF-kappaB signaling response to UVB light during cellular senescence. Exp. Cell Res., 248, 194-202 (1999).

27) Ray PD, Huang BW, Tsuji Y. Reactive oxygen species (ROS) homeostasis and redox regulation in cellular signaling. Cell. Signal., 24, 981-990 (2012). 